\title{
Analisis Kemampuan Komunikasi Matematis Mahasiswa pada Materi Geometri
}

\author{
Muhammad Turmuzi ${ }^{1}$, Wahidaturrahmi ${ }^{2}$, Eka Kurniawan ${ }^{3}$ \\ 1, 2, 3 Program Studi Pendidikan Matematika, FKIP Universitas Mataram \\ E-mail: tur.muzi@yahoo.co.id ${ }^{1}$,wahidaturrahmi@unram.ac.id ${ }^{2}, \underline{\text { ekakurniawan2892@unram.ac.id }}^{3}$
}

\begin{abstract}
Abstrak
Tujuan penelitian ini adalah untuk mengetahui kemampuan komunikasi matematis mahasiswa calon guru sekolah dasar pada materi Geometri. Metode penelitian ini adalah deskriptif kualitatif yang dianalisis dari instrumen yang diberikan. Instrumen dalam penelitian ini berupa 4 soal tes tertulis. Subjek penelitian ini adalah 34 mahasiswa di Program Studi Pendidikan Guru Sekolah Dasar FKIP Universitas Mataram. Indikator yang digunakan pada penelitian ini ada 4 indikator kemampuan komunikasi matematis yaitu menjelaskan ide matematik ke dalam bentuk gambar, menjelaskan ide, situasi dalam bentuk tulisan, menghubungkan gambar ke dalam ide matematika dan membaca dengan pemahaman suatu representasi matematika tertulis. Dari hasil analisis data diperoleh hasil kemampuan komunikasi matematis mahasiswa pada materi Geometri berada dalam kategori masih sangat rendah. Hal ini dapat dilihat dari hasil rekapitulasi jawaban mahasiswa dan hasil konversi skor mahasiswa dengan persentase berurutan sebesar $45,58 \%$ dan $50 \%$ terutama pada soal dengan indikator membaca dengan pemahaman suatu representasi matematika.
\end{abstract}

Kata Kunci: geometri, komunikasi matematis, mahasiswa calon guru

\section{Analysis of Students' Mathematical Communication Ability on Geometry Material}

\begin{abstract}
The purpose of this study was to determine the mathematical communication skills of prospective elementary school teacher students on Geometry material. This research method is descriptive qualitative analyzed from the given instrument. The instrument in this study was in the form of 4 written test questions. The subjects of this study were 34 students in the Primary School Teacher Education Study Program, FKIP, Mataram University. The indicators used in this study are 4 indicators of mathematical communication skills, namely explaining mathematical ideas in the form of images, explaining ideas, situations in written form, connecting images to mathematical ideas and reading with the understanding of a written mathematical representation. From the results of data analysis, it was found that the students' mathematical communication skills in the Geometry material were in the very low category. This can be seen from the results of the recapitulation of student answers and the results of the conversion of student scores with the successive percentages of $45.58 \%$ and $50 \%$, especially in questions with reading indicators with an understanding of a mathematical representation.
\end{abstract}

Keywords: geometry, mathematical communication, prospective teacher students 


\section{PENDAHULUAN}

Pembelajara matematika mempunyai fungsi sebagai sarana buat menyebarkan kepandaian kritis, logis, kreatif, dan bekerjasama yang diperlukan siswa dalam kehidupan yang semakin maju ini. Seperti tercantum pada buku satuan pendidikan dasar dan menengah mata pelajaran matematika bahwa mata pelajaran matematika perlu diberikan kepada semua peserta didik menurut sekolah dasar buat membekali peserta didik dengan kepandaian logis, analitis, sistematis, kritis, dan kreatif serta bekerjasama (Ratna, 2020: 53). Menurut Syarifah (2017: 51) matematika juga merupakan alat yang digunakan sebagai pola pikir baik berupa seni atau bahasa yang dapat dikomunikasikan buat merampungkan masalah. Jadi, matematika merupakan suatu alat yang dipakai untuk menerjemahkan simbol-simbol dengan cara mengorganisasikan pola pikir yang bisa didefinisikan dengan cermat, jelas, dan seksama representasinya berupa bahasa, simbol dan ide. Lebih lanjut dijelaskan bahwa kemampuan komunikasi merupakan jalan bagi berkembangnya matematika, dimana perannya yang dapat mengelaborasi buat menghubungkan pengetahuan-pengetahuan yang terdapat, sebagai akibatnya melahirkan pengetahuan baru yang bermanfaat. Tidak terdapat komunikasi maka tidak terdapat kegiatan saling memberi dan mendapat pengetahuan. Komunikasi merupakan bagian yang penting pada matematika. Lantaran melalui komunikasilah mahasiswa bisa bertukar pikiran dan gagasan serta dapat mengklarifikasi pemahaman dan pengetahuan selama proses belajar matematika

Kemampuan komunikasi matematis perlu untuk dikembangan lebih lanjut, hal ini disebabkan karena kemampuan komunikasi matematis merupakan suatu aktivitas yang sangat penting dalam kehidupan sehari-hari, dimana pada komunikasi terjadi aktifitas penyampaian informasi, baik itu pesan, inspirasi atau gagasan, menurut satu pihak ke pihak lainnya. Biasanya aktifitas komunikasi ini dilakukan secara lisan supaya memudahkan kedua belah pihak buat saling mengerti. (Tresno \& Risma, 2018: 18). Pentingnya komunikasi juga diungkapkan oleh Kadarisma (2018), Communication Skills atau kemampuan komunikasi adalah kemampuan yang sangat penting untuk dimiliki siswa dalam mempelajari matematika, siswa sekolah dasar maupun sekolah menengah diharuskan memiliki keterampilan komunikasi yang baik. Selain itu, menurut Baroody (1993) komunikasi matematika adalah modal dalam menyelesaikan, mengeksplorasi, dan menyelidiki matematika, dan merupakan sarana kegiatan sosial dalam bertukar ide, pendapat, dan dapat mempertajam gagasan dalam meyakinkan orang lain. Proses komunikasi bisa membantu mahasiswa menciptakan pemahamanya terhadap konsep-kosep pada matematika dan gampang dipahami. Komunikasi secara ekspresi juga tulisan bisa membawa mahasiswa dalam pemahaman yang mendalam tentang matematika. Grafik, bagan, diagram, lambang, simbol dan persamaan merupakan cara-cara komunikasi yng acapkali dipakai pada matematika. Tabel, diagram, dan grafik menuntun murid mengambil konklusi dan pertanyaan baru (Romlah, 2017: 38). Menurut NCTM atau National Council of Teacher mathematics (Rahmawati, 2019: 345), masih ada 5 kompetensi pada pembelajaran matematika, yaitu: pemecahan kasus matematik, komunikasi matematik, penalaran matematik, koneksi matematik, dan representasi matematik. Salah satu hal yang wajib diperhatikan menurut kelima kompetensi itu yaitu kemampuan komunikasi matematis.

Kendati kemampuan komunikasi matematis perlu dilatihkan kepada siswa atau mahasiswa. Namun dari beberapa hasil penelitian menunjukkan bahwa masih rendahnya kemampuan komunikasi mahasiswa atau siswa, seperti penelitian oleh Riyadi (2020: 78) menyimpulkan bahwa kemampuan komunikasi matematis untuk gaya belajar visual terletak pada kategori kemampuan rendah. Demikian juga halnya penelitian yang dilakukan oleh Nurlaili (2020: 120) menyebutkan bahwa hasil analisis kemampuan komunikasi mahasiswa setelah menggunakan pendekatan MEAs diperoleh bahwa kemampuan komunikasi matematis mahasiswa kategori rendah sebesar 41,38\%. Angka ini tergolong cukup tinggi. Penelitian yang sama oleh Tresno \& Risma (2018: 23), juga menyimpulkan kemampuan komunikasi matematis siswa SMP pada materi Segiempat dan Segitiga masih termasuk kategori sangat rendah. Rendahnya kemampuan komunikasi matematis pada Sekolah Menengah Pertama (SMP) disebabkan pengajar masih cenderung aktif, menggunakan pendekatan ceramah mengungkapkan materi pada para peserta didik sebagai akibatnya anak didik pada mengkomunikasi matematis masih sangat kurang (Darkasyi, 2014: 22). Pada ajang TIMSS tahun 2007 terlihat bahwa murid Indonesia masih lemah pada hal komunikasi matematik. Menurut hasil Trend in Mathematics 
and Scince Study (TIMSS) dalam tahun 2011 menampakan bahwa anak didik Indonesia yang mempunyai kemampuan komunikasi matematis hanya sebanyak 57\% dibandingkan negara lain yang 80\% siswanya telah mempunyai kemampuan komunikasi matematis, dimana hal ini menyebabkan Indonesia menempati urutan ke-45 dari 49 negara (Maudi, 2016: 39). Didukung menggunakan output penelitian yang dilakukan oleh Nurhayati (2014), ditemukan bahwa kemampuan komunikasi matematis murid masih tergolong rendah. Kurangnya keterlibatan murid pada aktivitas belajar mengajar, sebagai akibatnya pembelajaran yang cenderung berpusat dalam pengajar sebagai penyebab menurut rendahnya respon murid terhadap pelajaran matematika. Terdapat lebih dari separuh murid memperoleh skor kemampuan kurang menurut $60 \%$ dari skor ideal, sebagai akibatnya kualitas kemampuan komunikasi matematik murid belum mencapai kategori baik. Tidak jauh berbeda, keadaan seperti ini juga di alami oleh mahasiswa Program Studi Pendidikan Guru Sekolah Dasar (PGSD) FKIP Universitas Mataram. Kemampuan komunikasi matematis mahasiswa masih rendah. Dari hasil observasi yang dilakukan peneliti terhadap mahasiswa PGSD FKIP Universitas Mataram diperoleh informasi bahwa masih terdapat banyak mahasiswa yang salah dalam menginterpretasikan gambar geometri saat dihadapkan pada soal ujian terutama pada geometri bangun ruang. Mahasiswa juga masih kesulitan dalam menafsirkan benda nyata, kondisi dan pristiwa keseharian ke dalam model matematika. Mahasiswa juga sering keliru saat menjelaskan ide, dan simbol matematika ke dalam bahasa biasa. Hasil penelitian yang pernah dilakukan oleh Rosyidah (2020: 20) terhadap mahasiswa Program Studi PGSD FKIP Universitas Mataram menemukan mahasiswa juga sering tidak teliti di dalam menuliskan kembali komponen soal yang diberikan, salah di dalam menuliskan simbol bilangan yang dimaksud atau keliru dalam memberikan simbol positif atau negatif dari bilangan bulat, ataupun keliru menulis simbol operasi hitung bilangan.

Selanjutnya, NCTM dalam Principles and Standard for School Mathematics, merumuskan baku komunikasi buat mengklaim aktivitas pembelajaran matematika yang sanggup mengembangkan kemampuan siswa, yaitu: 1. Menyusun dan memadukan pemikiran matematika melalui komunikasi. 2. Mengkomunikasikan pemikiran matematika secara logis dan sistematis pada sesama siswa, guru, juga orang lain. 3. Menganalisis dan mengevaluasi pemikiran dan taktik matematik orang lain. 4. Menggunakan bahasa matematika buat mengekspresikan gagasan matematis secara tepat (Hodiyanto, 2017: 12). Sedangkan menurut Kadir (2008) bahwa buat mengungkap kemampuan anak didik pada aneka macam spek komunikasi, bisa dilakukan menggunakan melihat kemampuan anak didik pada mendiskusikan perkara dan menciptakan aktualisasi diri matematika secara tertulis baik gambar, contoh matematika, juga simbol atau bahasa sendiri. Lebih lanjut Kadir (2008) menyampaikan bahwa pengukuran kemampuan komunikasi matematis anak didik dilakukan menggunakan menaruh skor terhadap kemampuan anak didik pada menaruh jawaban soal menggunakan menggambar (drawing), menciptakan aktualisasi diri matematik (mathematical expression), dan menuliskan jawaban menggunakan bahasa sendiri (written texts). Pemberian skor jawaban anak didik disusun dari 3 kemampuan yaitu: (1). Menulis (written text), yaitu mengungkapkan inspirasi atau solusi menurut suatu konflik atau gambar menggunakan memakai bahasa sendiri. (2). Menggambar (drawing), yaitu mengungkapkan inspirasi atau solusi menurut konflik matematika pada bentuk gambar. (3). Ekspresi matematika (mathematical ekspression), yaitu menyatakan perkara atau insiden sehari-hari pada bahasa contoh matematika.

Adapun indikator berdasarkan kemampuan komunikasi matematis murid yang dikemukakan Sumarmo (Wijayanto, 2018: 98) menjadi berikut: a) Menyatakan benda-benda nyata, situasi dan insiden sehari-hari ke pada bentuk contoh matematika (gambar, tabel, diagram, grafik, aktualisasi diri matematika); b) Menjelaskan ide, dan contoh matematika (gambar, tabel, diagram, grafik, aktualisasi diri matematika); c) Menjelaskan dan menciptakan pertanyaan matematika yang dipelajari d) Mendengarkan, berdiskusi, dan menulis mengenai matematika; e) Membaca menggunakan pemahaman suatu presentasi tertulis; dan f) Membuat konjektur, menyusun argumen, merumuskan definisi dan generalisasi. Selain indikator di atas, Indikator digunakan dalam mencapai keterampilan komunikasi secara matematis menurut NCTM (Maharani \& Rahman, 2016: 132), adalah 1) Kompilasi dan asosiasikan pemikiran matematika mereka melalui komunikasi; 2) Berkomunikasi matematika berpikir Mereka secara logis dan jelas bagi teman-temannya, Guru, dan lainnya; 3) Analisis. dan menilai pemikiran matematika dan strategi yang digunakan oleh orang lain; 4) Gunakan Bahasa 
matematika untuk mengekspresikan ide matematika dengan benar. Sedangkan Indikator yang dipakai pada penelitian ini yaitu menyebutkan ide, situasi ke pada bentuk tulisan, menyebutkan ide matematik kedalam bentuk gambar, mengekspresikan konsep matematik menggunakan menyatakan gagasan sehari-hari pada simbol matematika dan menyelesaikannya, menghubungkan gambar ke pada ide matematika.

Berdasarkan uraian tentang indikator kemampuan komunikasi matematis di atas, maka pada penelitian ini indikator kemampuan komunikasi matematis yang digunakan adalah mengadopsi pendapat Sumarmo (Wijayanto, 2018: 98) dengan sedikit modifikasi menjadi: (1). Menjelaskan ide matematik ke dalam bentuk gambar serta menyatakan peristiwa sehari-hari dalam simbol matematika dan menyelesaikannya. (2). Menjelaskan ide, situasi dalam bentuk tulisan. (3). Menghubungkan gambar ke dalam ide matematika. (4). Membaca dengan pemahaman suatu representasi matematika tertulis.

\section{METODE}

Metode yang digunakan dalam penelitian ini adalah deskriptif kualitatif. Jenis penelitian ini adalah jenis penelitian yang bertujuan untuk mengetahui kondisi yang terjadi selama penelitian. Populasi yang menjadi subjek penelitian ini adalah semua mahasiswa Program Studi Pendidikan Guru Sekolah Dasar (PGSD) FKIP Universitas Mataram semester 2 yang menempuh mata kuliah Pendidikan Matematika Sekolah Dasar. Sampel penelitian ini diambil secara langsung tanpa mengubah kelas yang ada, yaitu mahasiswa kelas $2 \mathrm{i}$ sebanyak 34 mahasiswa. Penelitian ini bertujuan untuk menganalisis bagaimana keterampilan komunikasi matematika mahasiswa kelas $2 \mathrm{i}$ pada materi pembahasan geometri. Pengumpulan data dalam penelitian ini menggunakan 4 soal uji kemampuan komunikasi matematika.

Dalam menganalisis jawaban siswa, digunakan tehnik penskoran terhadap soal tes kemampuan komunikasi berdasarkan holistic scoring rubrics dari Cai, Lane dan Jakabcsin 1996 (Sriwahyuni et al., 2018: 20), sebagai berikut:

Tabel 1. Pedoman Penskoran Kemampuan Komunikasi Matematis

\begin{tabular}{ll}
\hline Skor & Kriteria \\
\hline 4. & $\begin{array}{l}\text { Dapat menjawab semua aspek pertanyaan tentang komunikasi matematis dan di jawab dengan } \\
\text { benar dan jelas atau lengkap }\end{array}$ \\
3. & Dapat menjawab hampir semua aspek pertanyaan tentang komunikasi dan dijawab dengan benar. \\
2. & $\begin{array}{l}\text { Dapat menjawab hanya sebagian aspek pertanyaan tentang komunikasi dan di jawab dengan } \\
\text { benar. }\end{array}$ \\
1. & Menjawab tidak sesuai atas aspek pertanyaan tentang komunikasi atau menarik kesimpulan salah \\
0. & Tidak ada jawaban
\end{tabular}

Untuk mengukur kemampuan komunikasi matematis siswa secara individu digunkan rumus sebagai berikut: Sriwahyuni et al., ( 2018)

Keterangan:

$$
P=\frac{X}{Y} x 100
$$

$\mathrm{P}=$ Tingkat Kemampuan Komunikasi matematis tiap individu

$\mathrm{X}=$ Skor total yang diperoleh oleh individu

$\mathrm{Y}=$ Skor maksimum tiap individu

Selanjutnya, hasil skor persentase mahasiswa kemampuan komunikasi matematika dikategorikan menjadi kategori yang sangat tinggi, tinggi, sedang, rendah, sangat rendah. Kategori ini dikonversi dengan menggunakan konversi penilaian oleh Nurkancana dan Sunarta (Nurul, Arifani, Sunardi, 2015) 
Tabel 2. Konversi Skor

\begin{tabular}{ll}
\hline Persentase & Kategori \\
\hline $90,00 \leq \mathrm{P} \leq 100$ & Sangat tinggi \\
$80,00 \leq \mathrm{P}<90,00$ & Tinggi \\
$65,00 \leq \mathrm{P}<80,00$ & Sedang \\
$55,00 \leq \mathrm{P}<65,00$ & Rendah \\
$\mathrm{P}<55,00$ & Sangat rendah \\
\hline
\end{tabular}

Setelah semua data hasil tes kemampuan komunikasi matematis mahasiswa dianalisis dapat disimpulkan bagaimana tingkat kemampuan komunikasi mahasiswa pada materi pokok geometri.

\section{HASIL DAN PEMBAHASAN}

Berdasarkan hasil tes kemampuan komunikasi matematis dan jawaban mahasiswa, serta setelah dianalisis dengan menggunkan holistic scoring rubrics dari Cai, Lane, \& Jakabcsin (Anwar, 2012). Berikut ini disajikagn tabel hasil rekapitulasi jawaban mahasiswa:

Tabel 3. Rekapitulasi Jawaban Mahasiswa

\begin{tabular}{lllll}
\hline $\begin{array}{l}\text { No } \\
\text { Soal }\end{array}$ & Indikator & $\begin{array}{l}\text { Jawaban } \\
\text { Benar }\end{array}$ & $\begin{array}{l}\text { Jawaban } \\
\text { Salah }\end{array}$ & $\begin{array}{l}\text { Tidak } \\
\text { Jawab }\end{array}$ \\
\hline 1. & $\begin{array}{l}\text { Menjelaskan ide matematik ke dalam bentuk gambar } \\
\text { serta menyatakan peristiwa sehari-hari dalam simbol }\end{array}$ & $\begin{array}{l}34 \\
\text { matematika dan menyelesaikannya }\end{array}$ & 0 & 0 \\
& Menjelaskan ide, situasi dalam bentuk tulisan. & $10 \%$ & $0 \%$ & $0 \%$ \\
2. & Menghubungkan gambar ke dalam ide matematika & $41,17 \%$ & $58,82 \%$ & $0 \%$ \\
& & 25 & 8 & 1 \\
3. & Membaca dengan pemahaman suatu representasi & 0 & $26,47 \%$ & $2,94 \%$ \\
& matematika tertulis. & $0 \%$ & $100 \%$ & $0 \%$ \\
\hline Total & & $53,67 \%$ & $45,58 \%$ & $0,73 \%$ \\
\hline
\end{tabular}

Dari hasil rekapitulasi jawaban mahasiswa hingga 4 item soal tentang kemampuan komunikasi matematis yang telah diberikan, sebanyak $53,67 \% \%$ mahasiswa yang menjawab dengan benar, 45,58\% mahasiswa menjawab secara tidak benar atau tidak lengkap dan sesuai, dan sebanyak 0,73\% mahasiswa yang tidak menjawab pertanyaan yang diberikan. Dalam pertanyaan nomor satu, $100 \%$ mahasiswa dapat menjawab dengan benar. Dalam pertanyaan nomor 2, antara mahasiswa yang menjawab dengan benar dan jawaban salah perbandingannya hampir berimbang, yaitu 41,17\% menjawab dengan benar serta 58,82\% menjawab salah. Untuk soal nomor 3 mahasiswa yang menjawab benar sebanyak $73,52 \%$ dan jawaban salah $26,47 \%$. Sedangkan untuk soal nomor 4 tidak ada satupun mahasiswa yang menjawab dengan benar. Jadi dari beberapa indikator pertanyaan yang digunakan, seluruh mahasiswa dapat menjawab dengan benar pada indikator yang menjelaskan ide matematik ke dalam bentuk gambar serta menyatakan peristiwa sehari-hari dalam simbol matematika dan menyelesaikannya, sementara dalam indikator lain, mahasiswa masih mengalami kesulitan memberikan jawaban yang benar.

Berikut ini diberikan beberapa contoh jawaban mahasiswa pada soal tes kemampuan komunikasi matematis mahasiswa yang paling banyak di jawab benar oleh mahasiswa

1. Dua buah silinder mempuyai volume sama. Tinggi silinder pertama empat kali tinggi silinder kedua. Jika jari jari silinder pertama $12 \mathrm{~cm}$. Tentukan jari jari silinder kedua.

Untuk indikator soal nomor 1 semua mahasiswa dapat menjawab dengan benar, meskipun jawaban akhir dari soal ini dijawab dengan benar tetapi terdapat beberapa mahasiswa yang masih kurang lengkap dalam langkah-langkah penyelesaian seperti tidak menulis hal yang diketahui dan hal yang ditanya dalam soal, berikut contoh jawaban mahasiswa untuk soal nomor 1 . 


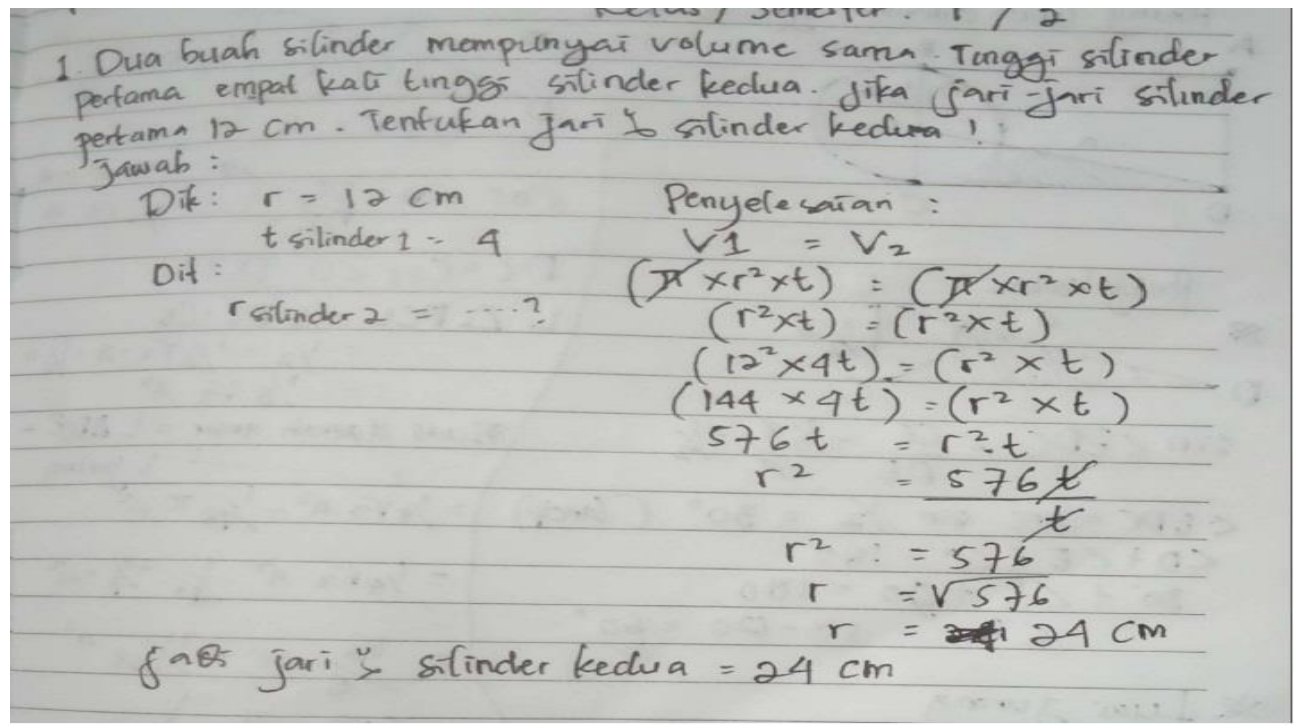

Gambar 1. Jawaban Mahasiswa soal nomor 1

Pada gambar 1 terlihat bahwa jawaban akhir sudah benar, tetapi penulisan simbol yang masih kurang tepat, seharusnya diketahui $R_{1}=12 \mathrm{~cm}, t_{1}=4 . t_{2}, V_{1}=V_{2}$, ditanya: nilai $R_{2}$. Pada soal ini jawaban akhir semua mahasiswa benar, akan tetapi penggunaan simbol dan ide penyelesaian masalah serta langkah penyelesaian masih kurang tepat.

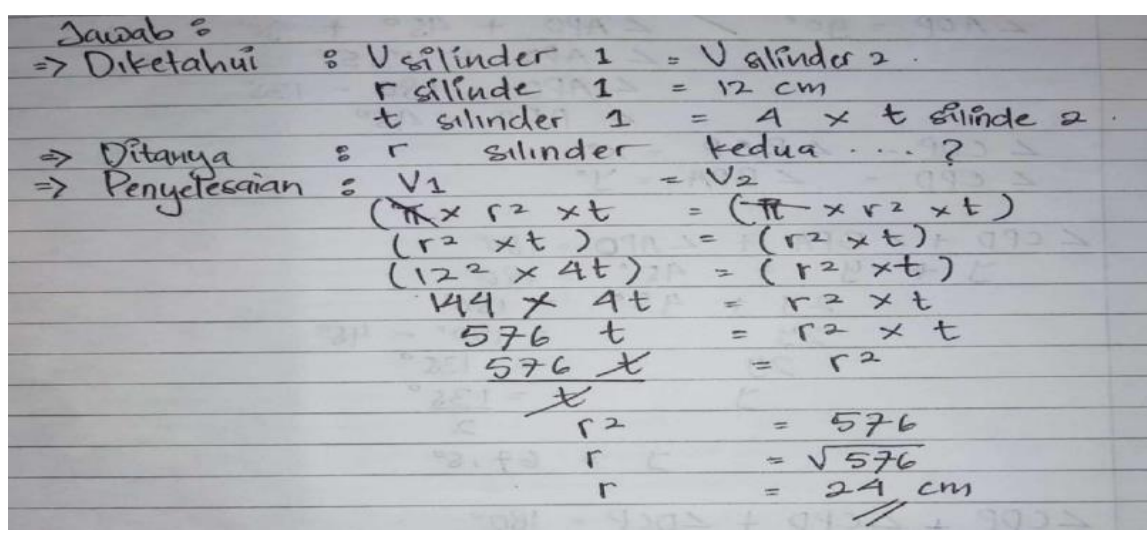

Gambar 2. Jawaban Mahasiswa soal nomor 1

Gambar 2 adalah jawaban mahasiswa yang hampir benar tetapi pada langkah awal penggunaan simbol masih kurang tepat seharusnya $\mathrm{V}_{1}=\mathrm{V}_{2}$ dan berikutnya $\pi \cdot r_{1}^{2} \cdot t_{1}=\pi \cdot r_{2}^{2} . t_{2}$ dan seterusnya.

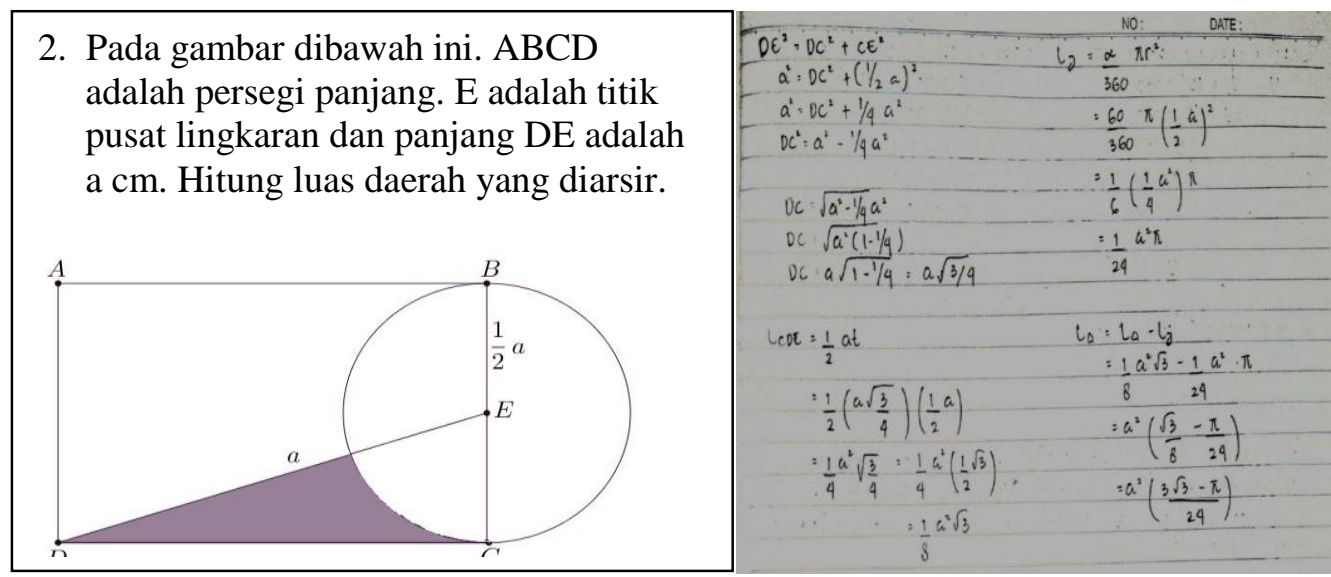

Gambar 3. Jawaban Mahasiswa benar soal nomor 2 


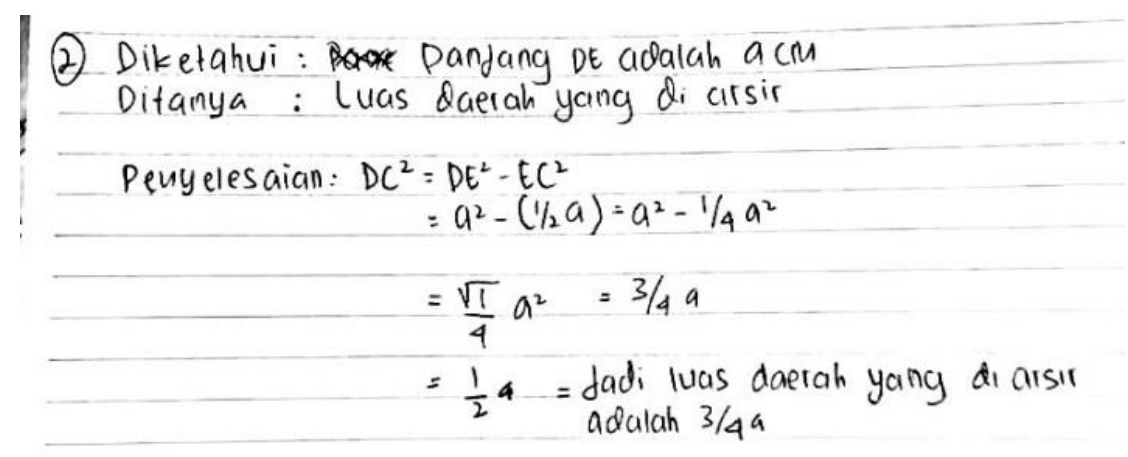

Gambar 4. Jawaban Mahasiswa salah soal nomor 2

Pada gambar 4 terlihat bahwa pemahaman konsep awal mahasiswa tidak memenuhi indikator dalam kemampuan komunikasi matematis, definisi dan notasi formal belum terbangun melalui situasi informal, istilah-istilah matematika dengan ekspresi yang dijumpai belum terpenuhi. Kenyataan ini sejalan dengan pendapat Umar (2012) yang menyebutkan bahwa untuk memperkenalkan dan menggunakan matematika sebagai bahasa komunikasi pada mahasiswa, perlu dilakukan dengan hatihati dan bertahap sesuai dengan tingkat intelektual mahasiswa. Ada 4 saran yang diberikan oleh Barody sehubungan dengan ini, yaitu (i) menggunakan aktivitas pengalaman bahasa: Dengarkan, bicara, baca, dan tulis; Dalam kegiatan ini mahasiswa dipandu untuk mengungkapkan reaksi, ide, dan perasaan yang berkaitan dengan situasi di kelas, (ii) definisi dan notasi formal harus dibangun melalui situasi informal, (iii) istilah matematika terkait dengan ekspresi sehari-hari yang ditemukan, (iv) Penting bagi mahasiswa untuk dapat membandingkan dan membedakan bahasa matematika dengan bahasa sehari-hari.

Konsep awal serta definisi dan notasi formal yang perlu dibangun adalah untuk menghitung luas daerah yang di arsir dimunculkan ide melalui pencarian dua luas daerah yang bersesuaian yaitu terlebih dahulu mencari luas daerah segitiga DCE dan mencari luas daerah juring lingkaran. Bila luas kedua daerah ini sudah ditemukan maka dapat dihitung luas daerah yang diarsir dengan rumus luas daerah segitiga DCE dikurangi luas daerah juring lingkaran.
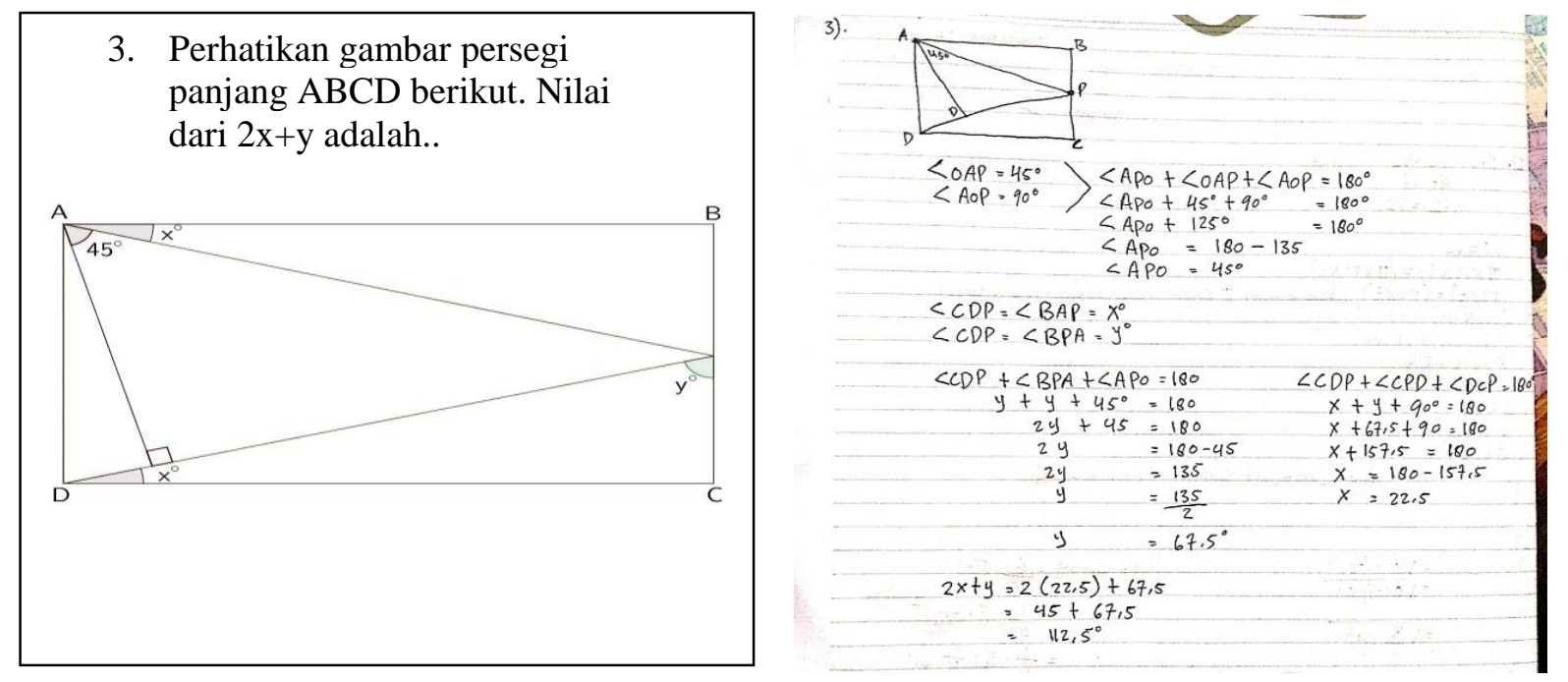

Gambar 5. Jawaban Mahasiswa benar soal nomor 3 


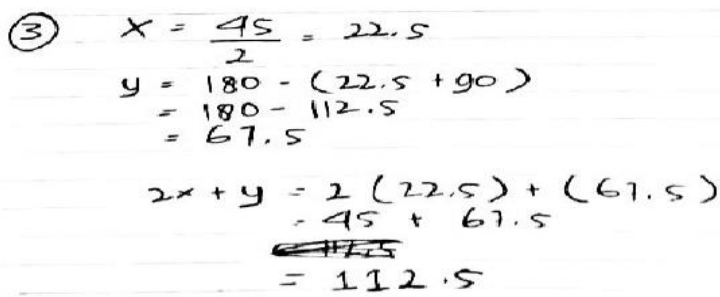

Gambar 6. Jawaban Mahasiswa salah soal nomor 3

Pada gambar 5 meskipun jawaban benar akan tetapi mahasiswa tidak menuliskan hal yang diketahui dan hal yang ditanya dalam soal. Sedangkan pada gambar 6 mahasiswa sulit mengkomunikasikan ide matematikanya akibat simbol-simbol matematika yang bersifat abstrak. Walaupun hasil akhirnya benar tetapi ada beberapa indikator komunikasi matematis yang tidak muncul pada langkah pengerjaan seperti tidak menghubungkan gambar ke dalam ide matematika, tidak menciptakan aktualisasi diri matematik (mathematical expression), dan tidak menuliskan jawaban menggunakan bahasa sendiri (written texts). Hal ini sejalan dengan pendapat Supriadi (2016), yang menyatakan bahwa pembelajaran matematika sulit dikomunikasikan karena terbentur dengan simbol-simbol yang bersifat abstrak. Banyak dari mahasiswa lamban belajar dan mengalami kesulitan dari segi pengucapan/lisan serta tulisan. Lebih lanjut dijelaskan bahwa mahasiswa tidak dapat mengulangi apa yang diucapkan dosen, mereka cenderung hanya mengikuti teman-teman mereka yang dianggap benar. Sedangkan dalam hal penulisan komunikasi mahasiswa tidak dapat menulis dengan benar bahkan ada mahasiswa yang tidak ingin menulis sama sekali, ini mengakibatkan keterampilan komunikasi mahasiswa menjadi terhambat dan tidak lancar. Demikian juga hasil penelitian Paradesa \& Ningsih $(2017,79)$ menyebutkan bahwa kemampuan mahasiswa dalam memahami simbol-simbol matematika, kemampuan berargumentasi dengan memberi bukti dan fakta masih rendah.Temuan penelitian ini memperkuat hasil penelitian Murtafiah (2016, 36-37) yang menyebutkan bahwa kemampuan mahasiswa dalam memahami soal yaitu menulis hal yang diketahui dan ditanyakan dalam soal masih rendah, demikian juga kemampuan mahasiswa dalam merencanakan dan menghubungkan gambar ke dalam ide matematika masih rendah. Beberapa mahasiswa juga salah dalam menuliskan simbol-simbol matematika.

Secara keseluruhan dari beberapa jawaban mahasiswa untuk soal nomor 1, nomor 2, dan nomor 3 walaupun hasil akhir sudah benar tapi proses pengerjaan soal dan hubungannya dengan kemampuan komunikasi matematis masih kurang. Kekurangan ini terkait ketidakmampuan mahasiswa dalam menghubungkan gambar ke dalam ide matematika. Fakta ini juga didukung oleh hasil penelitian Khoiriyah $(2016,208)$ yang menyimpulkan bahwa dalam proses menyelesaikan soal mahasiswa tidak mampu mendeskripsikan gambar dengan jelas, sehingga gambar sulit untuk dipahami. Hal ini juga sejalan dengan hasil penelitian Ramadhan $(2018,158)$, yang menyebutkan bahwa meskipun jawaban akhir adalah benar, proses ketika bekerja pada ini masih salah dalam menulis. Karena ketika menyelesaikan masalah yang dilakukan peserta didik sesuai dengan konsep apa yang dia tahu untuk menemukan solusi untuk menyelesaikannya masalah itu. Peserta didik yang menjawab pertanyaan dengan cara mereka sendiri, terperinci dan menjawab pertanyaan dengan benar menunjukkan bahwa peserta didik melakukan pola berpikir untuk mengatur bukti logis. 
4. Pada gambar dibawah ini diketahui $\mathrm{ABC}$ segitiga sama sisi. Sisi AC dan BC dibagi menjadi tiga bagian sama besar (kongruen). Jika luas segitiga $\mathrm{ABC}$ adalah $36 \mathrm{~cm}$ persegi. Maka hitunglah luas daerah yang di arsir.
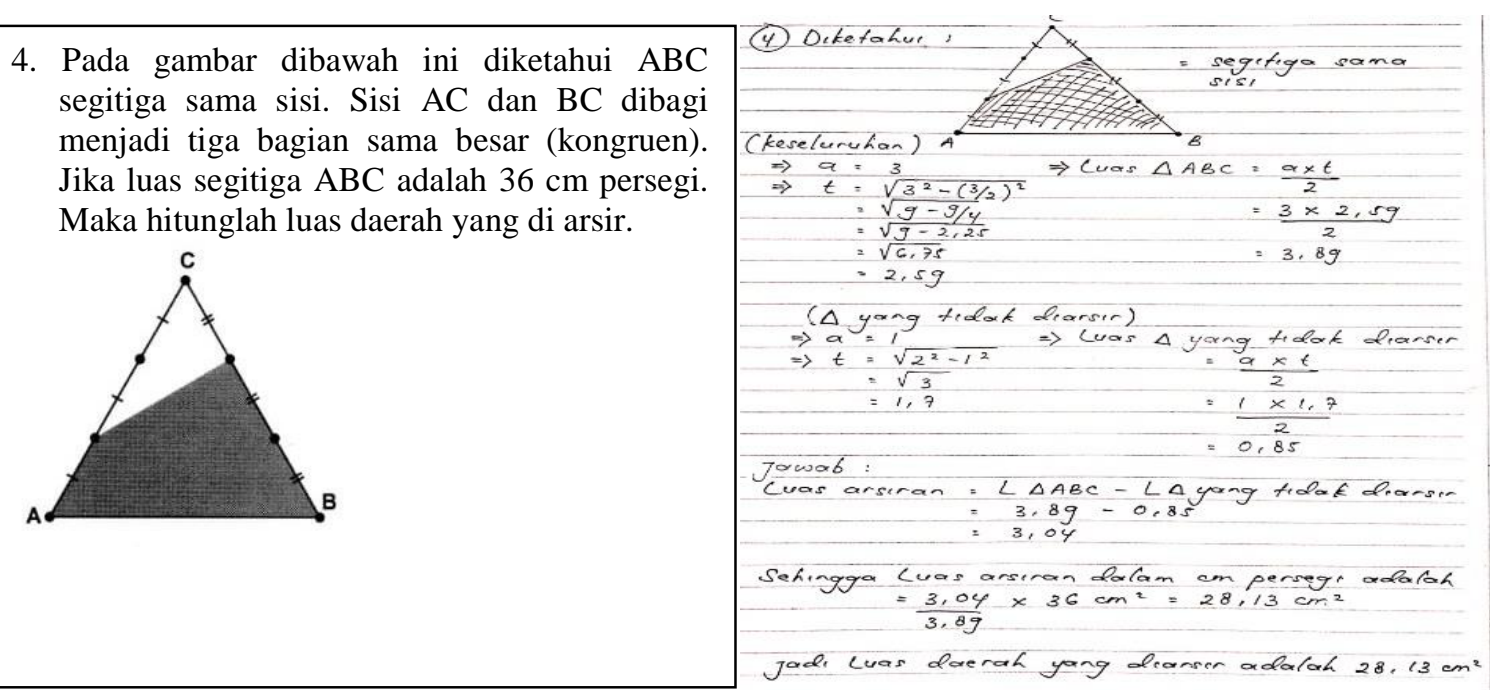

Gambar 7. Jawaban Mahasiswa salah soal nomor 4

Pada gambar 7 cara mahasiswa menyelesaikan soal cenderung menggunakan penyelesaian secara analitik, konseptual dan operasional. Secara analitik soal ini dapat diselesaikan, hanya saja membutuhkan langkah yang lebih panjang. Untuk soal nomor 4 ini semua jawaban mahasiswa tidak ada yang sesuai dengan indikator kemampuan komunikasi matematis. Soal nomor 4 ini ingin menguji cara membaca dengan pemahaman suatu representasi matematika tertulis dan kemampuan komunikasi matematis dengan lebih banyak merepresentasikan gambar. Jadi ide utamanya adalah dengan menarik garis bantu dari gambar yang sudah ada sehingga akan muncul ide atau gagasan yang dalam dan menyeluruh untuk mengeksplorasi ide matematika melalui gambar dan simbol-simbol. Ide matematis yang dapat dijalankan untuk menyelesaikan soal ini adalah dengan menggunakan garis bantu pada masing-masing titik pembagian segitiga. Dari garis bantu yang terhubung kita dapat merepresentasikan gambar baru yaitu terdapat 9 segitiga yang kongruen yang dapat dibentuk dari $\triangle \mathrm{ABC}$, katakana ke 9 segitiga yang kongruen tersebut kita beri nama $\triangle \mathrm{PQR}$.

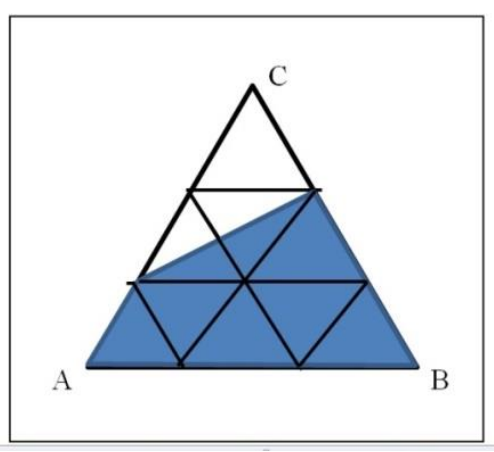

Gambar 8. Segitiga Kongruen pada Segitiga ABC

Dari gambar 8 terlihat bahwa terdapat $9 \triangle \mathrm{PQR}$ yang kongruen dan diketahui luas $\triangle \mathrm{ABC}=36$ $\mathrm{cm}$ persegi, akibatnya luas $9 \triangle \mathrm{PQR}=36$ dan diperoleh luas $\triangle \mathrm{PQR}=4 \mathrm{~cm}$ persegi. Perhatikan bahwa daerah yang di arsir terdiri dari $7 \triangle \mathrm{PQR}$. Jadi luas daerah yang diarsir menjadi 7 x $4=28 \mathrm{~cm}$ persegi. Namun ide representasi matematis seperti ini tidak dapat muncul dalam proses berpikir mahasiswa. Secara analitik soal ini dapat diselesaikan dengan bantuan kesebangunan dan perbandingan luas dua segitiga yaitu: 


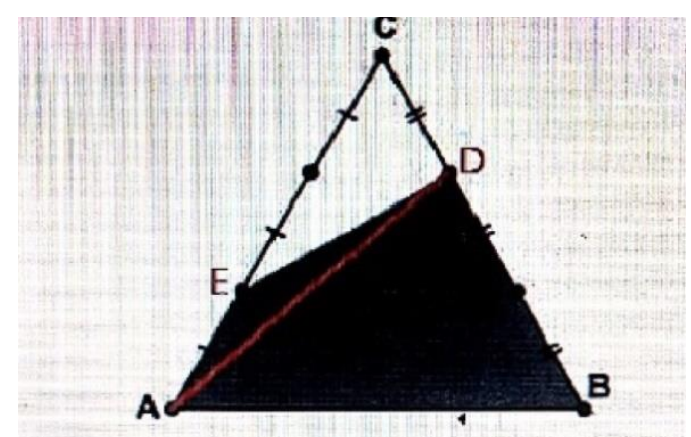

Gambar 9. Kesebangunan dan Perbandinan Luas Dua Segitiga

$$
\begin{aligned}
&-\frac{[A C D]}{[A B D]}=\frac{1}{2} \Rightarrow[\mathrm{ABD}]=2[\mathrm{ACD}] \\
& {[\mathrm{ABD}]+[\mathrm{ACD}]=36 } \Rightarrow 2[\mathrm{ACD}]+[\mathrm{ACD}]=36 \\
& \Rightarrow[\mathrm{ACD}]=12 \text { dan }[\mathrm{ABD}]=24 \\
&-\frac{[A D E]}{[E C D]}=\frac{1}{2} \Rightarrow[\mathrm{ECD}]=2[\mathrm{ADE}] \\
& {[\mathrm{ADE}]+[\mathrm{ECD}]=[\mathrm{ACD}] \Rightarrow[\mathrm{ADE}]+2[\mathrm{ADE}]=12 } \\
& \Rightarrow[\mathrm{ADE}]=4 \text { dan }[\mathrm{ECD}]=8
\end{aligned}
$$

Jadi luas daerah yang diarsir adalah $[\mathrm{ABD}]+[\mathrm{ADE}]=24+4=28 \mathrm{~cm}$ persegi.

Berdasarkan lembar jawaban mahasiswa pada soal nomor 4 ini secara umum dapat dikatakan bahwa ketika mahasiswa diminta menyusun konjektur, menyusun argument, merumuskan definisi dan generalisasi hasilnya masih banyak mengalami kesulitan. Pernyataan ini juga didukung oleh penelitian Nurlaila $(2018,1117)$ yang menyatakan bahwa saat peserta didik diminta membuat konjektur, menyusun argument, merumuskan definisi dan generalisasi, namun masih terdapat peserta didik yang mengalami kesalahan. Kesalahan tersebut adalah tidak mengetahui bentuk dari bangun geometri bidang datar tersebut, sehingga mereka tidak bisa merumuskan definisi, dan juga tidak bisa berargumen dengan benar mengenai permasalahan tersebut. Kemampuan peserta didik dalam membuat konjektur, menyusun argumen, merumuskan definisi dan melakukan generalisasi tergolong rendah yaitu hanya sebesar 7, 58\%. (Purwandari, 2018, 61). Sedangkan kesimpulan penelitian lain menyebutkan bahwa kemampuan peserta didik dalam membuat konjektur, menyusun argumen, merumuskan definisi dan generalisasi memperoleh nilai 1,10 dari skala 4 dengan persentase sebesar 27,49\% dan angka ini tergolong rendah (Niasih, 2019, 269). Peserta didik lebih paham merumuskan generlisasi dengan berbagai eksperimen secara visual dari pada harus selalu menggunakan rumus dan simbol-simbol (Bernard, 2014, 213)

Selanjutnya untuk dapat melihat kategori kemampuan komunikasi matematis mahasiswa, skor yang diperoleh kemudian dikonversi sesuai tabel konversi skor menurut Nurkancana \& Sunarta (Nurul, Arifani, Sunardi, 2015) menghasilkan Tabel 4.

Tabel 4. Kategori Kemampuan Komunikasi Matematis Mahasiswa

\begin{tabular}{lll}
\hline Kategori & f & \% \\
\hline Sangat Tinggi & 1 & 2.94 \\
Tinggi & 1 & 2.94 \\
Sedang & 7 & 20.58 \\
Rendah & 8 & 23.52 \\
Sangat Rendah & 17 & 50 \\
\hline
\end{tabular}

Dari Tabel 4 terlihat bahwa dari hasil konversi skor kemampuan komunikasi matematis mahasiswa kelas 2i sebanyak 17 mahasiswa berada dalam kategori sangat rendah dengan persentase $50 \%$ dan yang memiliki kemampuan tinggi hanya terdapat 1 orang yakni sebesar 2,94\%. 


\section{SIMPULAN}

Berdasarkan hasil penelitian yang telah dijelaskan, dapat disimpulkan bahwa kemampuan komunikasi matematis mahasiswa pada materi Geometri berada dalam kategori masih sangat rendah. Hal ini dapat dilihat dari hasil hasil rekapitulasi jawaban mahsiswa dan hasil konversi skor mahasiswa dengan persentase berurutan sebesar $45,58 \%$ dan $50 \%$ terutama pada soal nomo 4 dengan indikator, yaitu membaca dengan pemahaman suatu representasi matematika. Faktor-faktor yang mempengaruhi tingkat kapasitas komunikasi matematika mahasiswa anatara lain mahasiswa kurang menyeluruh dalam memahami masalah yang diberikan, mahasiswa tidak memahami penguasaan konsep geometri bangun bidang datar, mahasiswa tidak tahu dalam memecahkan masalah sehingga mahasiswa hanya mampu sampai memahami masalah.

\section{DAFTAR PUSTAKA}

Baroody. (1993). Problem Solving, Reasoning, and Communicating, K-8 Helping Childern Think Mathematically. New York: Macmillan Publishing Company

Bernard, M. (2014). Meningkatkan Kemampuan Penalaran Matematik Siswa Sma Melalui Game Adobe Flash Cs 4. Prosiding Seminar Nasional Pendidikan Matematika STKIP Siliwangi, 2, 205-213.

Darkasyi, M., Johar, R., \& Ahmad, A. (2014). Peningkatan Kemampuan Komunikasi Matematis dan Motivasi Siswa dengan Pembelajaran Pendekatan Quantum Learning pada Siswa SMP Negeri 5 Lhokseumawe. Jurnal Didaktik Matematika, 1(1), 21-34.

Hodiyanto. (2017). Kemampuan Komunikasi Matematis Dalam Pembelajaran Matematika. AdMathEdu, 7(1), 9-17.

Kadarisma, G. (2018). Penerapan Pendekatan Open-ended Dalam Meningkatkan Kemampuan Komunikasi Siswa SMP. ANARGYA: Jurnal Ilmiah Pendidikan Matematika, 1(2).

Kadir. (2008). Kemampuan Komunikasi Matematik dan Keterampilan Sosial Siswa Dalam Pembelajaran Matematika. Semnas Matematika dan Pendidikan Matematika 2008, 339-350.

Khoiriyah, S. (2016). Kemampuan Komunikasi Matematis Mahasiswa dalam Pemecahan Masalah Kalkulus II. Jurnal E-DuMath, 2(2), 202-209.

Maharani, Z. Z., \& Rahman, B. (2016). Penerapan Model Pembelajaran Think-Pair-Share untuk Meningkatkan Kemampuan Komunikasi Matematis Siswa SMP. I(2), 131-135.

Maudi, N. (2016). Implementasi Model Project Based Learning Untuk Meningkatkan Kemampuan Komunikasi Matematis Siswa. 39-43.

Murtafiah, W. (2016). Kemampuan Komunikasi Matematika Mahasiswa Calon Guru Matematika Dalam Menyelesaikan Masalah Persamaan Diferensial Ditinjau Dari Gender. Jurnal Math Educator Nusantara, 2(1), 31-41.

Niasih, N., Romlah, S., \& Zhanty, L. S. (2019). Analisis Kemampuan Komunikasi Matematis Siswa SMP di Kota Cimahi Pada Materi Statistika. Jurnal Cendekia : Jurnal Pendidikan Matematika, 3(2), 266-277. https://doi.org/10.31004/cendekia.v3i2.107

Nurlaila, S. Sariningsih, R. Maya, R. (2018). Analisis kemampuan komunikasi matematis siswa smp terhadap soal-soal bangun ruang sisi datar. Jurnal Pembelajaran Matematika Inovatif, 1(6), $1113-1120$.

Nurlaili, Rifanti, U. M., \& Ananda, R. (2020). Analisis Kemampuan Komunikasi Matematis Mahasiswa pada Aplikasi Graf Menggunakan Pendekatan MEAs. Jurnal Gantang, 5(2), 113- 
121. https://doi.org/10.31629/jg.v5i2.2515

Nurul, H., Arifani, Sunardi, S. S. (2015). Tingkat Kemampuan Berpikir Kreatif Matematika Siswa SMP Kelas VIII di SMP Negeri 6 Jember, SMP Al Furqan 1, SMP Negeri 1 Rambipuji, dan SMP PGRI 1 Rambipuji. KADIKMA, 6(2), 159-172.

Paradesa, R., \& Ningsih, Y. L. (2017). Pembelajaran Matematika Berbantuan Maple Pada Mata Kuliah Kalkulus Integral Terhadap Kemampuan Komunikasi Matematis Mahasiswa. Jurnal Pendidikan Matematika RAFA, 3(1), 70-81.

Purwandari, A. S., Astuti, M. D., \& Yuliani, A. (2018). Evaluasi Kemampuan Komunikasi Matematis Siswa SMP Pada Materi Sistem Persamaan Linear Dua Variabel. IndoMath: Indonesia Mathematics Education, 1(1), 55-62. https://doi.org/10.30738/indomath.v1i1.2219

Ramadhan, I., Minarti, E. D., Lingkaran, S., Of, J., Journal, M., Mathematics, O., \& Ikip, E. (2018). Kajian Kemampuan Komunikasi Matematik Siswa SMP dalam Menyelesaikan Soal Lingkaran pembelajaran matematika yang memiliki IX SMP pada materi lingkaran . Manfaat. Journal of Medives : Journal of Mathematics Education IKIP Veteran Semarang, 2(2), 151-161.

Rahmawati, N. S., Bernard, P. A. M. (2019). Analisis Kemampuan Komunikasi Matematik Siswa SMK Pada Materi Sistem Persamaan Linier Dua Variabel (SPLDV). Journal On Education, 01(02), 344-352.

Ratna, S. G. K. (2020). P2M STKIP Siliwangi P2M STKIP Siliwangi. Jurnal Ilmiah P2M STKIP Siliwangi P2M STKIP Siliwangi, 5(2), 1-6.

Riyadi, M. H. P. (2020). Kemampuan Komunikasi Matematis Siswa Ditinjau dari Gaya Belajar. Indiktika : Jurnal Inovasi Pendidikan Matematika, 3(1), 71-80.

Romlah, S., Kadarisma, G., \& Setiawan, W. (2017). Analisis Kemampuan Komunikasi Matematik Siswa SMP Mutiara 1 Bandung Pada Materi Bentuk Aljabar. Jurnal On Education, 01(02), 3746.

Rosyidah, A. N. K., Maulyda, M. A., \& Oktaviyanti, I. (2020). Miskonsepsi Matematika Mahasiswa PGSD Pada Penyelesaian Operasi Hitung Bilangan Bulat. Jurnal Ilmiah KONTEKSTUAL, 2(01), 15-21. https://doi.org/10.46772/kontekstual.v2i01.244

Supriadi, N. D. R. (2016). Analisis Kemampuan Komunikasi Matematis Siswa Lamban Belajar dalam Menyelesaikan Soal Bangun Datar Nanang. 7(1), 1-9.

Syarifah, L. L. (2017). Analisis Kemampuan Komunikasi Matematis Mahasiswa Pada Materi Integral. Prima: Jurnal Pendidikan Matematika, 1(1), 49. https://doi.org/10.31000/prima.v1i1.254

Tresno, S., \& Risma, A. R. M. (2018). Analisis Kemampuan Komunikasi Matematis Siswa SMP Pada Materi Segiempat dan Segitiga. Jurnal Kajian Pembelajaran Matematika, 3(1), 18-23. http://journal2.um.ac.id/index.php/jkpm

Umar, W. (2012). Membangun kemampuan komunikasi matematis dalam pembelajaran matematika. INFINITY : Jurnal Ilmiah Program Studi Matematika, 1(1).

Wijayanto, A. D., Fajriah, S. N., \& Anita, I. W. (2018). Analisis kemampuan komunikasi matematis siswa smp pada materi segitiga dan segiempat. 2(1), 97-104. 